be accommodated by a single tetramer? This also brings up the general question of other subunits that may alter the function or be necessary for some essential properties. The only evidence on the possible role of other subunits is that both ROMK1 and IRK1 display similar properties when expressed as single clones in oocytes, as identified from expression of total messenger RNA from the original tissues. Such similarity suggests that other subunits are not necessary for the properties of the currents seen with total mRNA.

There are several aspects to the significance of these new channel clones. They identify a hitherto unknown family of potassium channels and allow detailed mechanistic work on their properties. They further substantiate the importance of sequences in the $\mathrm{H} 5$ region for potassium permeation and selectivity. And they raise interesting questions about the nature of KAT1-like channels. Do these channels represent another class of inward rectifiers with a greater degree of intrinsic voltage-dependence of gating, thus making them more closely related to the voltage-gated Shaker-like channels? If so how do they achieve activation by hyperpolarization? The answers to these questions and other family secrets will no doubt be revealed shortly.

Richard Aldrich is in the Department of Molecular and Cellular Physiology, and the Howard Hughes Medical Institute, Stanford University, Stanford, California 94305, USA.

\title{
Green sea, black mud
}

\section{Constance Sancetta}

To the occupants of a space shuttle ten million years ago, the geography of the Earth would have looked only slightly different from its modern form. The Mediterranean was larger, and portions of southern Europe were submerged beneath shallow seaways, producing a somewhat miscellaneous grouping of islands and peninsulas. The Alps and Himalayas were lower, and had considerably less snow cover. In the eastern equatorial Pacific, there was no junction between North and South America; the Isthmus of Panama did not exist, and the Pacific and Atlantic oceans mingled their waters through a tropical seaway. So much has been known for decades.

We now learn that an instrument such as the Coastal Zone Color Scanner would have revealed a further anomaly: vast areas of this region were apparently covered by floating mats of diatom algae. The mats, each several tens of centimetres square, were probably grouped into massive patches by wind action, with the total area affected being the size of Australia. On page 141 of this issue, Kemp and Baldauf ${ }^{1}$ report that this occurred repeatedly, and probably periodically, between fifteen million and about four and a half million years ago.

Basing their conclusions on a series of sediment cores recovered by the Ocean Drilling Program, the authors report a hierarchical clustering of mat-producing events, each alternating with conditions more like those of the present. The clustering runs from annual events, producing individual millimetre-scale laminae, to decimetre-scale beds representing periods of hundreds to a few thousand years. The latter can be corre- lated between sites 2,000 miles apart, implying that for prolonged periods, conditions throughout the region were favourable for mat production.

Such mats are not unknown in the modern world, as the authors point out. They can be formed by several genera of diatoms, all characterized by an elongate cell geometry. It is the spatial extent and the repetitive nature of the sediment mats that render them so fascinating. The conditions under which mats occur are not well understood; it may be a combination of cellular positive buoyancy and calm sea-surface conditions which permits them rise to the surface ${ }^{2}$. Once there, they may persist for weeks. Although the growth rate of the cells may not _be particularly high, the sheer number and spatial extent of the mats results in a marked reduction of nutrients and production of biomass. When the cells lose buoyancy, the mats settle rapidly to the sea floor, carrying large quantities of pristine organic matter to the sediments ${ }^{3}$.

Kemp and Baldauf make a second important point here. The laminated sediments were formed under reducing conditions, so that the organic matter was not oxidized and remained at relatively high concentrations. Such sediments, termed sapropels (from Greek sapros, decay, and pelos, mud) are often found in settings where high organic input occurs in a semi-enclosed basin with limited circulation, leading to stagnant bottom waters with little or no dissolved oxygen. The most famous example is the Black Sea. So frequent is this association that it has come to be axiomatic among sedimentologists that sapropelic sediments automatically imply anoxic bottom waters. As Kemp and Baldauf indicate, this need not be true. The overlying water column may be well oxygenated, provided that the sediment itself is reducing and that diffusion between water and sediment is limited. In the case of the diatom mats, the authors suggest that the dense meshwork prevented burrowing organisms from penetrating the sediments, thus limiting oxygen exchange.

A similar explanation may be true for the Pleistocene sapropels of the eastern Mediterranean, some of which also consist of diatom-mat laminae ${ }^{4}$. Some workers have called on conditions in which strong contrasts in salinity, possibly resulting from Nile flooding ${ }^{5}$, produced density stratification sufficient to limit deep water exchange through the entire region, thus supposedly producing anoxic bottom waters. In light of the findings in the eastern Pacific, it seems equally likely that existence of a stable surface water layer supported the production of mat-forming diatoms, whose deposition on the sea floor produced organic-rich sediment laminae below an oxygenated water column. At the least, we should re-examine the assumption of anoxic bottom waters wherever sapropels occur.

An intriguing point is that the mat production ceased about 4.4 million years ago. Kemp and Baldauf suggest a reduction in nutrient availability as the cause, but do not speculate on the conditions leading to such a reduction. Geochemical evidence has been used to infer that the gradual closure of the Isthmus of Panama resulted in a measurable differentiation of surface Atlantic and Pacific waters as far back as 4.0 million years ago (ref. 6). Possibly the increasing restriction of the seaway, both vertical and lateral, altered the water circulation in the eastern equatorial Pacific so as to affect either the nutrient supply or the physical conditions favouring mat formation.

In the late Miocene, there was no peak in Darien, and certainly no Spanish explorers. But if, by some miracle, Vasco de Balboa had been allowed to survey this vast sea, with its mats of algal green heaving gently upon the long-rolling waves, he might still have named it l'Oceano Pacífico, the peaceful ocean. $\square$

Constance Sancetta is at the Division of Ocean Sciences of the National Science Foundation, Washington DC 20550, USA.

1. Kemp, A. \& Baldauf, J. Nature 362, 141-144 (1993).

2. Villareal, T. \& Carpenter, E. J. Biol. Oceanogr. 6. $387-405$ (1989)

3. Sancetta, C., Villareal, T. \& Falkowski, P. Limnol. Oceanogr. 36, 1452-1457 (1991)

4. Schrader, H. \& Matherne, A. Micropaleontology 27. 191-203 (1981).

5. Rossignol-Strick, M., Nesteroff, W., Olive, P. \& Vergnaud-Grazzini, C. Nature 295, $105-110$ (1982)

6. Keigwin, L. Science 217, 350-353 (1982). 